\title{
Biological Features of Bone Marrow Mesenchymal Stromal Cells in Childhood Acute Lymphoblastic Leukemia
}

\author{
Çocukluk Çağı Akut Lenfoblastik Lösemisinde Kemik Iliği Mezenkimal Stroma Hücrelerinin \\ Biyolojik Özellikleri
}

(D) Stella Genitsari ${ }^{1}$, (D) Eftichia Stiakaki ${ }^{1}$, (D) Chryssoula Perdikogianni ${ }^{2}$, (D) Georgia Martimianaki ${ }^{3}$, (D) Iordanis Pelagiadis ${ }^{4}$, (D) Margarita Pesmatzoglou ${ }^{1}$, (D) Maria Kalmanti ${ }^{5}$, (D) Helen Dimitriou ${ }^{1}$

${ }^{1}$ Crete University Faculty of Medicine, University Hospital of Heraklion, Department of Pediatric Hematology and Oncology, Crete, Greece

${ }^{2}$ Crete University Faculty of Medicine, Department of Pediatrics, Crete, Greece

${ }^{3}$ Crete University Faculty of Medicine, Division of Mother and Child Health, Crete, Greece

${ }^{4}$ Metropolitan Hospital, N. Faliro, Athens, Greece

${ }^{5}$ Private Sector

\section{Abstract}

Objective: Mesenchymal stromal cells (MSCs) have a supportive role in hematopoiesis and as components of the bone marrow (BM) microenvironment may present alterations during acute lymphoblastic leukemia (ALL) and be affected by chemotherapeutic agents. We examined the biological and functional characteristics of MSCs in ALL diagnosis and treatment and their effect on MSC qualitative properties.

Materials and Methods: Immunophenotypic characterization, evaluation of clonogenicity, and proliferative capacity were measured. Apoptotic features, cell-cycle analysis, and stromal cell-derived factor $1 \alpha$ and angiopoietin-1 levels in MSC supernatant at diagnosis and in different phases of treatment were assessed. Chemotherapy was administered according to the Berlin-Frankfurt-Munster-2000 protocol. BM samples from children with solid tumors without BM involvement were used as the control group.

Results: The morphology, the immunophenotypic profile, and the apoptotic characteristics of the MSCs were not affected by leukemia. The secretion of factors involved in the trafficking of hematopoietic cells in the BM seems to be upregulated at diagnosis in comparison to the treatment phases. MSCs are influenced by the disease in terms of their functional characteristics such as clonogenicity and proliferation rate. These effects cease as soon as treatment is initiated. Chemotherapy does not seem to exert any effect on any of the MSC features examined.

Conclusion: MSCs from children with ALL are affected by their interaction with the leukemic environment, but this phenomenon ceases upon treatment initiation, while no effect is observed by chemotherapy itself.

Keywords: Bone marrow microenvironment, Childhood leukemia, Mesenchymal stromal cells, Stromal cell-derived factor $1 \alpha$

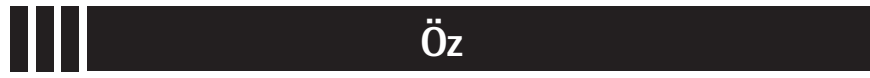

Amaç: Mezenkimal stroma hücreleri (MSH) hematopoezde destek rolü oynar, kemik iliği (KI) mikroçevresinin parçası olduklarından akut lenfoblastik lösemide (ALL) değişikliğe uğrayabilir ve kemoterapötik ajanlardan etkilenebilirler. Bu çalışmada, ALL'de tanı anında ve tedavide MSH'lerin biyolojik ve fonksiyonel özellikleri ile bunların MSH'lerin niteliksel özellikleri üzerine olan etkilerini araştırdık.

Gereç ve Yöntemler: İmmünofenotipik özellikler, klonalite değerlendirilmesi ve çoğalma kapasitesi ölçümleri yapıldı. Tanıda ve tedavinin değişik evrelerinde MSH süpernatanında apoptotik özellikler, hücre döngüsü analizi ve stromal hücre türevi factor-1 $\alpha$ ile anjiyopoietin-1 düzeyleri değerlendirildi. Kemoterapi olarak BerlinFrankfurt-Munster-2000 protokolü uygulandı. Solid tümörü olan ve KI tutulumu bulunmayan hastaların Ki örnekleri kontrol grubu olarak kullanıldı.

Bulgular: MSH'lerin morfoloji, immünofenotipik profil ve apoptotik özellikleri açısından lösemiden etkilenmediği görüldü. Hematopoetik hücrelerinin Ki'de yer değiştirmesi üzerine etkisi olabilen faktörlerinin salınımının tanıda, tedavi evrelerine göre upregüle olduğu tespit edildi. MSH'ler hastalıktan klonalite ve çoğalma hızı gibi fonksiyonel özellikler kapsamında etkilenmekteydi. Bu etkiler tedavi başlanması ile duraklamaktaydı. Kemoterapinin incelenen MSH özelliklerinden hiçbiri üzerine bir etkisi olmadığı görüldü.

Sonuç: ALL'si olan çocuklardaki MSH'ler lösemik çevre ile ilişkilerden etkilenir, ancak bu fenomen tedavi başlanması ile duraklar ve bu çalışmada kemoterapinin bunun üzerine bir etkisi gözlenmemiştir.

Anahtar Sözcükler: Kemik iliği mikroçevresi, Çocukluk çağı lösemisi, Mezenkimal stroma hücreleri, Stromal hücre türevi factor-1 $1 \alpha$ 


\section{Introduction}

Mesenchymal stromal cells (MSCs) constitute part of the bone marrow (BM) microenvironment where the survival, proliferation, and differentiation of hematopoietic stem cells (HSCs) take place [1]. Despite the large amount of information on the nature of MSCs, they have not been fully characterized so far. The in vivo counterparts or possibly precursors of culturedeveloped MSCs are currently considered to be perivascular cells, namely pericytes. These two-cell populations share similar properties in terms of marker expression, ability to self-renew, and potential to differentiate into multiple cell types such as adipocytes, chondrocytes, osteocytes, and myocytes under specified culture conditions $[2,3]$. The BM microenvironment is believed to play a pivotal role in the development and progression of leukemia [4]; thus, it is reasonable to speculate that MSCs may also be involved in the perturbation of normal hematopoiesis. Their putative role in oncogenesis and leukemogenesis has not been fully clarified and the results from the studies already published are contradictory. In vitro studies have shown that MSCs from newly diagnosed adult patients with leukemia (acute myeloid leukemia and acute lymphoblastic leukemia) are less efficient for supporting normal hematopoietic progenitor cell survival and this functional capacity is partially restored after chemotherapy [5]. Their implication in childhood ALL has only recently being addressed, revealing that ALLMSCs display reduced proliferative capacity and ability to support long-term hematopoiesis in vitro while those isolated at diagnosis did not differ from those obtained during treatment [6]. The detection of leukemia-associated genetic aberrations in MSCs implied a clonal relationship between MSCs and leukemia cells in childhood ALL and suggested the involvement of MSCs in the pathogenesis of the disease [7]. Involvement of MSCs in various malignancies via deregulation of the secretion of chemokines $[8,9,10]$ implies that they mediate cell migration and homing [11]. Stromal cellderived factor $1 \alpha$ (SDF-1 $\alpha$ or CXCL12) was found to retain and support the HSCs in the BM via the SDF- $1 \alpha / C X C R 4$ axis $[12,13]$. CXCL12 is constitutively secreted by marrow stromal cells, being the major source for CXCL12 in adults [14]. Less is known about its role in hematological malignancies and how it could be affected during chemotherapy. The existing studies have come to conflicting results $[8,15]$. Angiopoietin-1 (Ang1), initially known for its role in both embryonic and postnatal angiogenesis, has recently been reported to interact with HSCexpressed Tie-2 $[3,16]$, enhancing the maintenance of HSCs in a quiescent state within the BM, and Ang-1 is thereby part of the network regulating the "stemness" of HSCs [17].

MSCs have been considered promising candidates for cell therapies and, in view of their potential, there are many ongoing studies to understand their properties, mechanisms of action, and putative role in hematological malignancies $[7,18,19,20]$. So far MSCs from different sources have been shown to exhibit different properties [21]. Moreover, BM MSCs from children seem to be different from their adult counterparts [22].

The aim of this study is to characterize MSCs derived from the $\mathrm{BM}$ of children with ALL at the onset of the disease in order to evaluate the leukemic effect, if any, on their biological/ functional properties. In addition, an attempt was made to compare this population with the MSCs derived from the BM during different treatment phases for the assessment of the effect of chemotherapy on these features.

\section{Materials and Methods}

\section{Patients}

BM samples from children with B-lineage ALL and $>90 \%$ BM infiltration at diagnosis, hospitalized from 2006 to 2010 at the Department of Pediatric Hematology and Oncology, University Hospital of Heraklion, were studied. They included samples at diagnosis $(d, n=28)$, day $15(d 15, n=12)$, day 33 of induction therapy $(\mathrm{d} 33, \mathrm{n}=20)$ when remission was achieved, at intensification-consolidation (consol, $n=33$ ), during maintenance (maint, $n=19$ ) therapy, and at the end of treatment (end, $\mathrm{n}=20$ ), all in remission. MSCs examined at different phases of ALL treatment are not necessarily in all cases from the same patients. Patients were treated according to the ALL BerlinFrankfurt-Munster-2000 protocol and their risk stratification [medium risk (MR) and high risk (HR)] according to the same protocol was considered in some of the employed assays. The control group $(n=15)$ consisted of BM samples from children with solid tumors without BM involvement. Patients' ages ranged from 1.2 to 18 years (median: 6 years). The study was approved by the Ethical Committee of the University Hospital of Heraklion.

Methods are described in more detail in the Appendix (Supplementary Materials and Methods).

\section{BM Mononuclear Cells (MNCs) Isolation and MSC Culture and Expansion}

BM MNCs, following Ficoll-Hypaque separation $(1077 \mathrm{~g} / \mathrm{mL}$; Lymphoprep, Nycomed, Oslo, Norway), were cultured in a-MEM as described previously for MSC development [22]. MSCs were maintained for up to five passages. Assays were performed at any of P1 to P4 depending on the cell availability.

\section{Immunophenotyping Evaluation}

Phenotypic characterization of MSCs was performed by flow cytometry at various passages using hematopoietic cell and MSC-specific monoclonal antibodies (BD Biosciences, San Jose, CA, USA). One hundred thousand cells were stained with the markers as described previously [23]. At least 10,000 events were acquired for each analysis. 


\section{Cell Doubling Time (DT)}

DT was calculated according to the formula DT $=t / n=t \times \log (2) / \log$ (cells harvested/cells inoculated), where $t$ is the time between initial plating and harvest for the respective passage.

\section{Colony Forming Units-Fibroblast (CFU-F) Formation}

At day $0,1 \times 10^{5} \mathrm{MNC}$ s were seeded in each well of a 24-well plate (in triplicate) in the absence of fibroblast growth factor-2 (FGF2). At subsequent passages, MSCs were plated in $20-\mathrm{cm}^{2}$ petri plates at a concentration of 10 cells $/ \mathrm{cm}^{2}$ (in duplicate). The colonies that developed were categorized according to their size as small (S), medium (M), and large (L, highly proliferating) CFU-F. The sum of all sizes is denoted as CFU-F.

\section{Cell-Cycle Analysis - Apoptosis}

MSCs at either P2 or P3 were stained with propidium iodide in order to estimate the percentage of cells in each phase of the cell cycle. Cell-cycle analysis was performed using WinMDI software version 2.8 [24].

Apoptotic MSCs at passages P2 and P4 were detected by flow cytometry and 7-amino-actinomycin D (7-AAD; Sigma, St. Louis, MO, USA) staining [25].

\section{Detection of SDF-1 $\alpha$ and Ang-1 (ELISA)}

A quantitative sandwich enzyme-linked immunosorbent assay technique (ELISA) was employed for the determination of both SDF- $1 \alpha$ and Ang- 1 (R\&D Systems, Minneapolis, MN, USA) in the supernatant of MSCs at any of P1 to P3 cultures (and of MNCs at d0) within the leukemia group only, at diagnosis, and during treatment phases following the instructions of the manufacturer.

\section{Statistical Analysis}

Results are expressed as mean \pm standard error of the mean mean (SEM). Differences between groups were assessed using the nonparametric Mann-Whitney U-test and p-values lower than 0.05 were considered as statistically significant. Analysis was performed using SPSS 18.0 (SPSS Inc., Chicago, IL, USA).

\section{Results}

\section{Morphology and Immunophenotypic Profile}

BM MSCs from all groups were expanded until the fifth passage and all displayed the characteristic spindle-shape morphology. Immunophenotypic assays at P2 and P4 did not identify any differences among groups. MSCs at diagnosis expressed CD90 (99.67 $\pm 0.09 \%), C D 105(97.39 \pm 0.72 \%), C D 146$ (59.55 $\pm 2.84 \%)$, CD29 (99.1 $\pm 0.12 \%), C D 44(98.07 \pm 1.39 \%), C D 95(90.25 \pm 2.85 \%)$, and CD73 $(99.4 \pm 0.4 \%)$, while there was no expression of hematopoietic markers such as CD34, CD45, and CD14. The same immunophenotypic profile was also observed at all treatment phases and in the control group.

\section{Growth Rate of MSCs (DT)}

MSCs within the MNC fraction (d0) at diagnosis reached confluency in approximately $20.71 \pm 1.24$ days, whereas at the end of chemotherapy they required $15.10 \pm 0.63$ days. The DT at

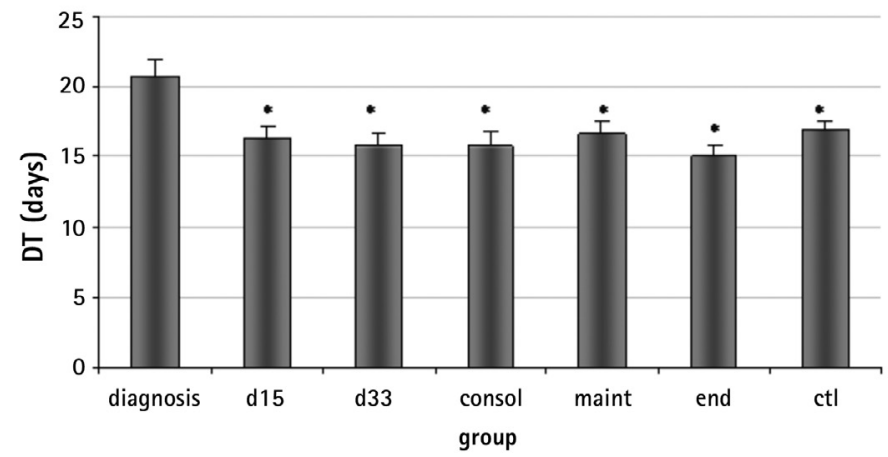

Figure 1. Days required for mesenchymal stromal cells in the mononuclear cells fraction (d0) to reach confluency. The doubling time at diagnosis differs from that of the phases of chemotherapy ( $p: \mathrm{d} 15=0.042, \mathrm{~d} 33=0.007$, consol $=0.001$, maint $=0.022$, end $=0.002$ ) and of the control $(p=0.011)$. This defect subsides with the progression of culture ( ${ }^{*}$ : ss in comparison to the d group).

\begin{tabular}{|l|l|l|l|l|l|}
\hline \multicolumn{6}{|c|}{ Table 1. Doubling time of mesenchymal stromal cells of all groups in the different passages (P1-P5). } \\
\hline $\mathrm{d}$ & $\mathbf{P 1}$ & $\mathbf{P 2}$ & $\mathbf{P 3}$ & $\mathbf{P 4}$ & P5 \\
\hline $\mathrm{d} 15$ & $3.30 \pm 0.41$ & $3.07 \pm 0.58$ & $4.20 \pm 0.80$ & $5.37 \pm 1.06$ & $4.75 \pm 0.95$ \\
\hline $\mathrm{d} 33$ & $2.39 \pm 0.31$ & $5.49 \pm 1.18$ & $4.80 \pm 1.22$ & $3.83 \pm 0.97$ & $3.82 \pm 0.69$ \\
\hline Consol & $2.57 \pm 0.24$ & $2.86 \pm 0.35$ & $3.47 \pm 0.42$ & $3.85 \pm 0.61$ & $3.82 \pm 0.41$ \\
\hline Maint & $2.59 \pm 0.19$ & $2.72 \pm 0.23$ & $3.24 \pm 0.30$ & $4.12 \pm 0.61$ & $4.50 \pm 0.93$ \\
\hline End & $3.44 \pm 0.53$ & $5.98 \pm 1.17$ & $3.57 \pm 0.49$ & $3.18 \pm 0.52$ & $4.21 \pm 0.50$ \\
\hline CTL & $2.49 \pm 0.20$ & $2.59 \pm 0.25$ & $2.57 \pm 0.32$ & $3.41 \pm 0.38$ & $3.73 \pm 0.40$ \\
\hline Data are expressed as mean \pm standard error of mean. CTL: Cytotoxic lymphocyte & & $4.42 \pm 0.25$ & $4.41 \pm 1.07$ & \\
\hline
\end{tabular}


diagnosis was statistically different compared to all the phases of treatment (Figure 1). At subsequent passages, DT was similar among all groups (Table 1). This finding indicates that MSCs present in the MNC fraction at diagnosis, which was mainly constituted of lymphoblasts, expanded more slowly compared to treatment phases and the control group, but this defect subsided with the progression of culture (more advanced P). No difference was observed among all passages in all other studied groups. As the culture progressed, DT increased in all groups and the control.

\section{CFU-F Development}

At day 0 , the CFU-F formation at diagnosis appeared to be impaired compared to the other groups (Figure 2), a result attributed to the lower number of the medium and the large-sized colonies. The impaired clonogenicity of MSCs at the time of diagnosis was a

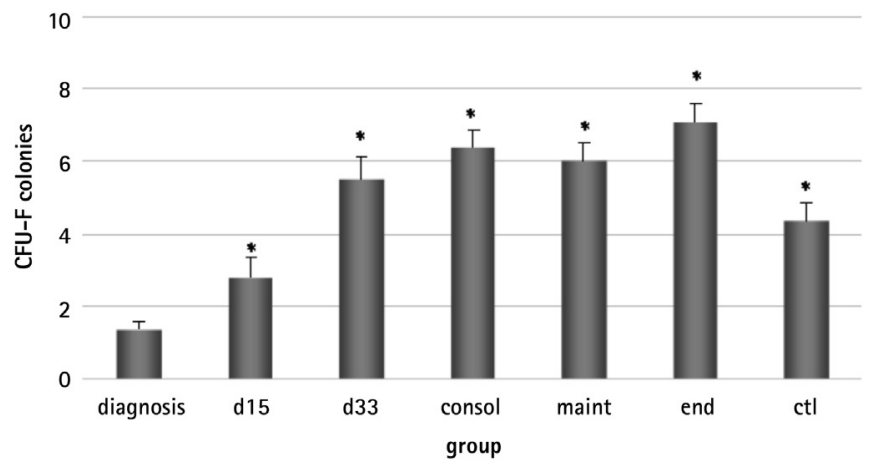

Figure 2. Colony forming units-fibroblast development of mesenchymal stromal cells in the mononuclear cells fraction (d0) from all studied groups. The number of colonies at diagnosis is lower than that of the other groups ( $d$ vs. end, control: $p<0.0001$ ). Culture progression resulted in lower colony development, becoming significant at the later passages.

Data are expressed as mean \pm SEM $\left(^{*}: p<0.05\right.$ compared to diagnosis).

CFU-F: Colony forming units. constant finding, observed at subsequent passages as well (Table 2). Culture progression resulted in lower colony development, the control included, and this became statistically significant at the later passages (P1 vs. P4 or P5, p<0.001). MSCs at diagnosis formed fewer small, medium, and large colonies compared to all other groups. Larger colonies prevailed at early passages, while at the later ones, the CFU-F population consisted of mainly small colonies (Supplementary Figure 1).

\section{Cell-Cycle Analysis - Apoptosis}

Most of the MSCs were in quiescence, presenting a higher percentage of cells in the G0G1 phase compared to the control group (Figure 3). The study of apoptosis in all phases of disease and treatment at P2 and P4 confirmed the stability of BM-MSCs under long-term culture expansion through serial passages. Spontaneous apoptosis was detected at P2 and it did not change at P4 in all groups (Table 3 ).

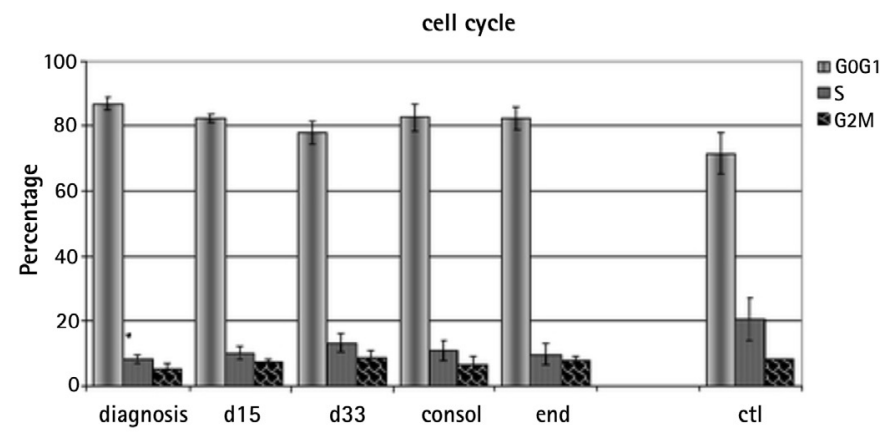

Figure 3. Analysis of the cell-cycle phases. Most of the mesenchymal stromal cells are in quiescence as the highest percentage of cells are in the G0G1 phase.

Data are expressed as mean \pm SEM.

\section{SDF-1 $\alpha$ and Ang-1}

SDF-1 $\alpha$ in the MSC supernatants at diagnosis was variably expressed (median: $5334.63 \mathrm{pg} / \mathrm{mL}$, range: $1066.70-22,480.86 \mathrm{pg} / \mathrm{mL}$ )

\begin{tabular}{|c|c|c|c|c|c|}
\hline$d$ & $26.80 \pm 2.79$ & $21.39 \pm 3.63$ & $19.61 \pm 4.69$ & $23.59 \pm 3.45$ & $19.46 \pm 3.55$ \\
\hline $\mathrm{d} 15$ & $45.08 \pm 5.72^{*}$ & $34.96 \pm 5.44^{*}$ & $37.73 \pm 6.01^{*}$ & $17.59 \pm 3.48$ & $7.82 \pm 2.21$ \\
\hline d33 & $38.52 \pm 3.52^{*}$ & $41.40 \pm 2.87^{*}$ & $32.06 \pm 3.51^{*}$ & $21.11 \pm 2.90$ & $17.11 \pm 2.41$ \\
\hline Maint & $46.15 \pm 3.28^{*}$ & $33.63 \pm 3.99^{*}$ & $31.93 \pm 2.63^{*}$ & $26.50 \pm 3.32$ & $15.12 \pm 2.02$ \\
\hline End & $48.34 \pm 4.43^{*}$ & $41.23 \pm 4.48^{*}$ & $34.20 \pm 4.28^{*}$ & $24.50 \pm 3.52$ & $29.00 \pm 3.30$ \\
\hline CTL & $57.27 \pm 4.47^{*}$ & $43.53 \pm 3.71^{*}$ & $37.38 \pm 5.40^{*}$ & $35.67 \pm 3.2^{*}$ & $38.83 \pm 6.05^{*}$ \\
\hline
\end{tabular}



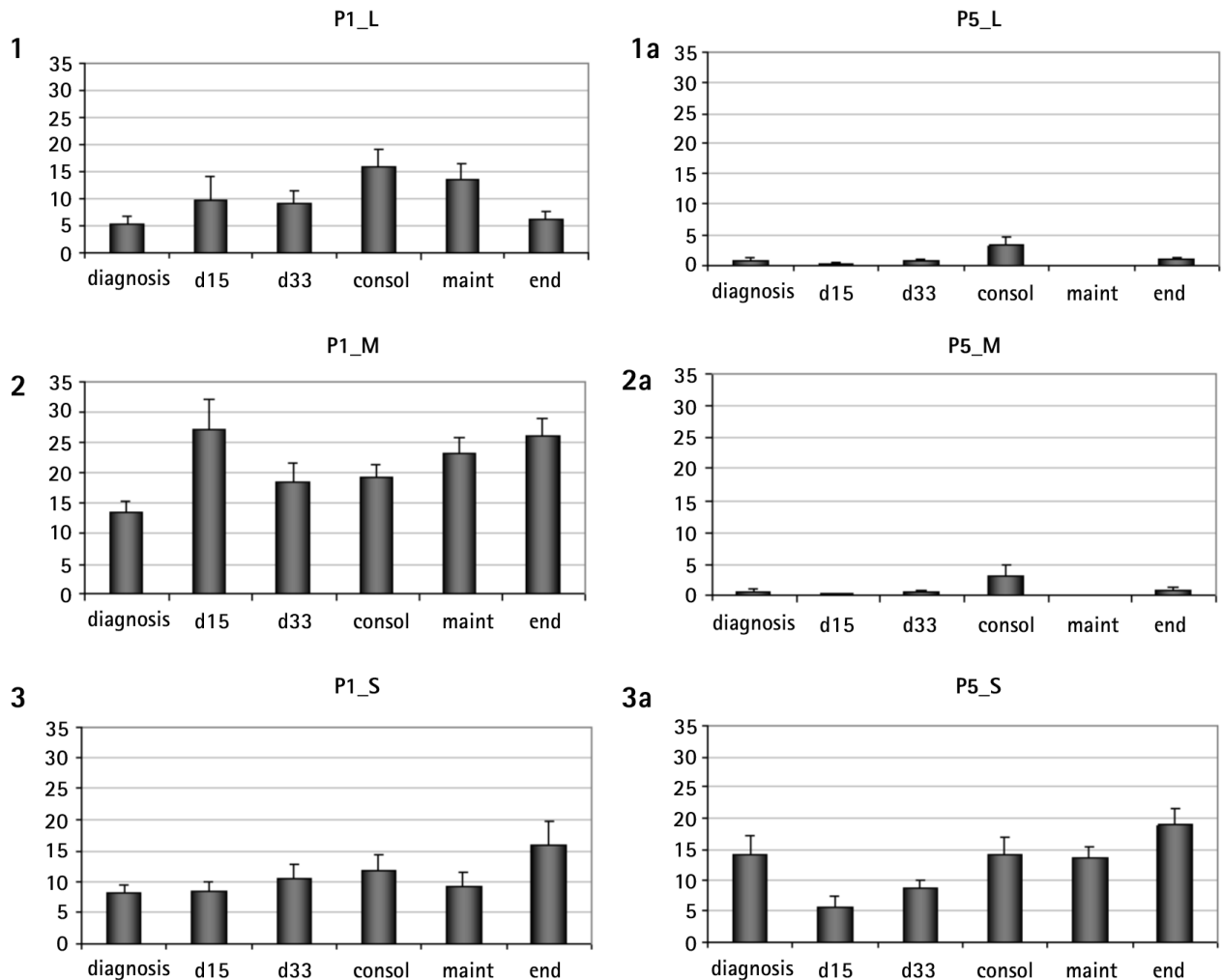

Supplementary Figure 1. Colony forming units-fibroblast (CFU-F) colonies of large (L), medium (M), and small (S) size at the initial (P1) and last (P5) passages of the study. Larger colonies prevail at early passages while at the later ones the CFU-F population consists of mainly small colonies.

\begin{tabular}{|c|c|c|c|c|}
\hline \multirow[t]{2}{*}{ Study group } & \multicolumn{2}{|c|}{ P2 (\%) } & \multicolumn{2}{|c|}{ P4 (\%) } \\
\hline & A & D & A & D \\
\hline$d$ & $4.92 \pm 2.38$ & $2.5 \pm 0.94$ & $3.47 \pm 0.97$ & $2.37 \pm 1.15$ \\
\hline d15 & $2.48 \pm 0.86$ & $1.97 \pm 1.21$ & $2.82 \pm 0.65$ & $1.97 \pm 1.21$ \\
\hline d33 & $2.65 \pm 0.59$ & $1.07 \pm 0.56$ & $1.42 \pm 0.27$ & $0.52 \pm 0.25$ \\
\hline Consol & $2.01 \pm 0.45$ & $1.4 \pm 0.38$ & $2.2 \pm 0.32$ & $1.05 \pm 0.21$ \\
\hline Maint & $1.97 \pm 0.38$ & $0.97 \pm 0.57$ & $1.2 \pm 0.65$ & $1.67 \pm 1.2$ \\
\hline End & $2.94 \pm 0.93$ & $3.78 \pm 1.33$ & $1.62 \pm 0.77$ & $1.45 \pm 1.02$ \\
\hline CTL & $1.75 \pm 0.29$ & $0.58 \pm 0.16$ & $0.92 \pm 0.37$ & $0.27 \pm 0.14$ \\
\hline
\end{tabular}

and did not differ in comparison with the treatment phases. Its levels were higher in the HR group compared to the MR group $(H R=9205.77 \pm 2721.82, M R=6686.11 \pm 4006.34, p=0.021)$.

As far as Ang-1 expression is concerned, in the two cell subpopulations of MNCs and MSCs, our results showed that, similar to SDF- $1 \alpha$, stromal cells secreted statistically significant higher amounts of this growth factor (Figure 4). No difference was found in the comparison of diagnosis with treatment groups.

\section{Discussion}

MSCs are described as fibroblast-like cells, displaying a characteristic spindle shape, and all of our cells exhibited this feature. As in vitro culture progresses, cells enter senescence and MSCs become larger with irregular and flat shapes [26], not observed in our samples. Our source though was the BM of children, albeit leukemic BM, and our culture was followed up to P5 [27]. 
A

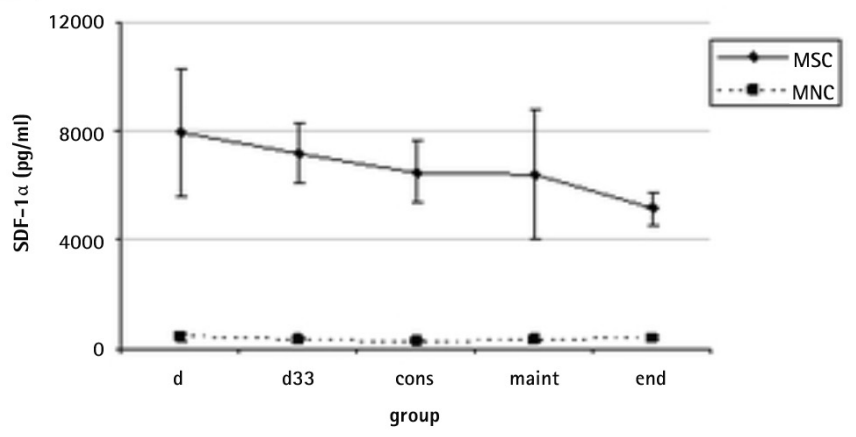

B

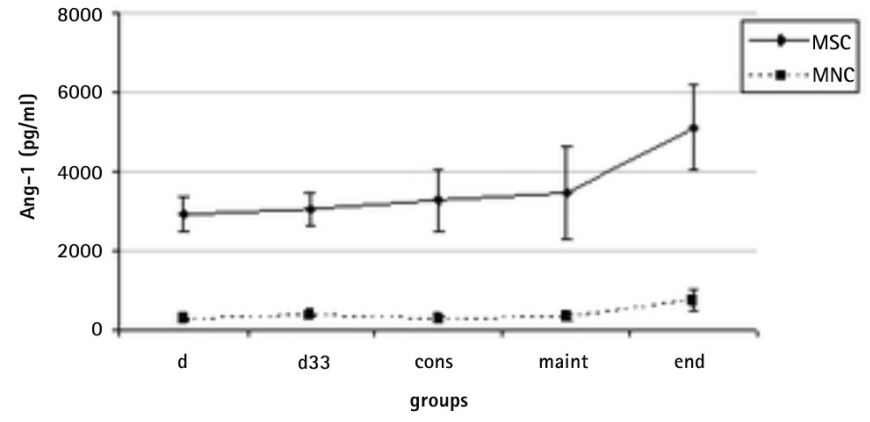

Figure 4. The stromal cell-derived factor-1 $\alpha$ (SDF-1 $\alpha)$ and angiopoietin-1 (Ang-1) expressions by both mesenchymal stromal cells (MSCs) and mononuclear cells (MNCs) at diagnosis and treatment. Stromal cells secrete higher amounts of both these factors. A) Variability in their expression was noticed at diagnosis, which became more uniform in treatment phases. B) No difference in angiopoietin-1 levels between diagnosis and treatment groups.

MSC: Mesenchymal stromal cell, MNC: mononuclear cell, Ang-1: angiopoietin-1, SDF-1 $\alpha$ : stromal cell-derived factor- $1 \alpha$.

MSCs from all groups at different passages were highly expressing MSC-related markers and lacking the hematopoietic markers, as proposed by the International Society for Cell Therapy $[28,29]$. This indicates that the MSC cultures were homogeneous, in agreement with Conforti et al. [6], and neither disease nor treatment had any influence on them. Clonogenicity and proliferation potential were lower at diagnosis and decreased as the culture progressed, in partial agreement with the onlystudy, so far, examining the characteristics of pediatric ALL-MSCs [6]. The lowest number of colonies was developed at diagnosis. Although this result does not stand alone to support that it is an intrinsic defect (because of the effect of the disease on MSCs) rather than a quantitative one, due to the lower frequency of MSCs in BM infiltrated by leukemic cells combined, with the fact that it continues to be seen in subsequent passages, where the same number of MSCs are used to initiate the culture, it is more suggestive of the hypothesis that the microenvironment (as expressed by BM MSCs) is also affected by the leukemic process. This result favors the observation of Conforti et al. [6] that leukemic cells do not confer to MSCs any preferential ability to proliferate, but they rather promote a deficient capacity, opposing the hypothesis that MSC populations might be crucial for the efficient promotion of the survival and proliferation of blasts [30]. Treatment does not affect the clonogenicity as the number of colonies produced at any time-point is similar to that of the controls. Another factor involved in colony development is the duration of the culture. Interestingly, the decrease of colony number throughout passages is more profound in largeand medium-sized colonies. Considering that large colonies derive from more primitive cells, it becomes obvious that older cultures contain more mature MSCs. Altogether, the above indicate that the presence of leukemia cells at diagnosis, but not chemotherapeutic agents, modifies BM-MSC properties.

Cell-cycle analysis revealed that most of the MSCs are in quiescence while about $20 \%$ of the cells of the control group are at the S phase, compared to less than $10 \%$ of the rest of the groups. Further analysis is required in order to fully clarify this difference found under identical culture conditions. Apoptosis remained unaltered throughout passages, a finding reported for BM-MSCs from children with benign hematological disorders [26]. Conforti et al. [6] reported different results, but they evaluated apoptosis for many passages and reported data for the latest one (P18).

Finally, we evaluated the levels of SDF-1 $\alpha$ and Ang-1, recently revealed as major regulators in the crosstalk between hematopoietic progenitors and their microenvironment [31,32]. Data reporting the expression of SDF- $1 \alpha$ by BM MSCs in patients with hematological malignancies are limited. SDF- $1 \alpha$ in the supernatant of MSCs at diagnosis of ALL was slightly increased compared to that from treatment phases, although this difference was not statistically verified. Interestingly, HR patients exhibited higher levels compared to the MR ones, a difference no longer occurring upon treatment initiation. Reduced extracellular levels of SDF- $1 \alpha$ were assessed in hematological malignancies of adults $[33,34]$. Others found increased SDF- $1 \alpha$ secretion from MSCs at diagnosis in adolescents and young adults with ALL, reversed by chemotherapy [6]. In pediatric patients with acute leukemia, SDF-1 $\alpha$ serum levels differed depending on whether they were evaluated in PB or BM serum (decreased expression) or MSC supernatants at diagnosis (decrease not evident) compared to the remission and control groups [15]. The above, combined with our findings, further support the notion that leukemic cells do not affect CXCL12 production and the decrease reported in serum cannot be attributed to the productive capacity of MSCs.

We found that the lowest amount of Ang-1 was expressed in MSC culture supernatant from diagnosis, albeit not statistically differently from treatment phases. There is one more study to date, on the effect of Ang-1 in childhood ALL [35], in which the authors claimed similar findings in the MSC supernatant and low levels of Ang-1 and Ang-2 in BM serum at diagnosis. Nevertheless, other factors such as age-related 
post-transcriptional effect on the expression of proteins or the exposure of BM MSCs to fetal bovine serum and FGF-b [36] have to be taken into consideration in order to fully exploit the role of these molecules in leukemia.

\section{Study Limitation}

A limitation of our study is that the samples examined at different phases of ALL are not necessarily from the same patients longitudinally. This approach ensures a reasonable number of samples within a reasonable timeframe for each group for a rather rare pediatric entity and hence a stronger statistical result.

\section{Conclusion}

In conclusion, biological characteristics and functional properties of MSCs are affected at the onset of leukemia. Most defects persist throughout passages. MSCs recover after treatment initiation and remission achievement and are not affected by chemotherapy. Their secretory profile remains unaltered by the disease. The summing of these data clearly indicates that any effect on MSCs from the leukemic clones in childhood ALL is transient and ceases upon treatment initiation. A standard hurdle in the comparison of our data to other studies continues to be the diversity of working protocols used for MSC cultures and further evaluation.

\section{Acknowledgments}

The authors would like to thank Kaparou Maria and Fillipides Anthi for their contributions in the performance of a number of experiments, Choumerianou Despina for her contribution in experiments and helpful suggestions, and Koutala Helen for technical advice and support in flow cytometry.

\section{Ethics}

Ethics Committee Approval: The study was approved by the Ethical Committee of the University Hospital of Heraklion.

\section{Authorship Contributions}

Medical Practices: E.S., M.K., C.P.; Concept: H.D., I.P., C.P., E.S.; Design: H.D., I.P., C.P., E.S.; Data Collection or Processing: S.G., H.D., G.M., I.P., M.P.; Analysis or Interpretation: S.G., M.P., H.D., I.P., C.P., E.S., M.K.; Literature Search: S.G., I.P., H.D., G.M., Writing: H.D.; S.G., C.P.

Conflict of Interest: The authors of this paper have no conflicts of interest, including specific financial interests, relationships, and/or affiliations relevant to the subject matter or materials included.

Financial Disclosure: This work was partially supported by the European $6^{\text {th }}$ Framework Program GENOSTEM (contract no: 503161) and the University of Crete Secretariat Research Committee (KA 3769).

\section{References}

1. El Marsafy S, Larghero J, Bennaceur-Griscelli A, Turhan A. Mesenchymal stem cells: pivotal players in hematopoietic stem cell microenvironment. J Stem Cell Res Ther 2014;4:225

2. Wong SP, Rowley JE, Redpath AN, Tilman JD, Fellous TG, Johnson JR. Pericytes, mesenchymal stem cells and their contributions to tissue repair. Pharmacol Ther 2015;151:107-120.

3. Sacchetti B, Funari A, Michienzi S, Di Cesare S, Piersanti S, Saggio I, Tagliafico E, Ferrari S, Robey PG, Riminucci M, Bianco P. Self-renewing osteoprogenitors in bone marrow sinusoids can organize a hematopoietic microenvironment. Cell 2007;131:324-336.

4. Sanchez-Aguilera A, Mendez-Ferrer $\mathrm{S}$. The hematopoietic stem-cell niche in health and leukemia. Cell Mol Life Sci 2017;74:579-590.

5. Sorokina T, Shipounova I, Bigildeev A, Petinati N, Drize N, Turkina A, Chelysheva E, Shukhov 0, Kuzmina L, Parovichnikova E, Savchenko V. The ability of multipotent mesenchymal stromal cells from the bone marrow of patients with leukemia to maintain normal hematopoietic progenitor cells. Eur J Haematol 2016;97:245-252.

6. Conforti A, Biagini S, Del Bufalo F, Sirleto P, Angioni A, Starc N, Li Pira G, Moretta F, Proia A, Contoli B, Genovese S, Ciardi C, Avanzini MA, Rosti V, Lo-Coco F, Locatelli F, Bernardo ME. Biological, functional and genetic characterization of bone marrowderived mesenchymal stromal cells from pediatric patients affected by acute lymphoblastic leukemia. PLoS One 2013;8:e76989.

7. Shalapour S, Eckert C, Seeger K, Pfau M, Prada J, Henze G, Blankenstein $T$ Kammertoens T. Leukemia-associated genetic aberration in mesenchymal stem cells of children with acute lymphoblastic leukemia. J Mol Med (Berl) 2010;88:249-265.

8. Ge J, Hu Y, Gui Y, Hou R, Yang M, Zeng Q, Xia R. Chemotherapy-induced alteration of SDF-1/CXCR4 expression in bone marrow-derived mesenchymal stem cells from adolescents and young adults with acute lymphoblastic leukemia.J Pediatr Hematol Oncol 2014;36:617-623.

9. Azab AK, Runnels JM, Pitsillides $C$, Moreau AS, Azab F, Leleu X, Jia X, Wright $R$, Ospina B, Carlson AL, Alt C, Burwick N, Roccaro AM, Ngo HT, Farag M, Melhem MR, Sacco A, Munshi NC, Hideshima T, Rollins BJ, Anderson KC, Kung AL, Lin CP, Ghobrial IM. CXCR4 inhibitor AMD3100 disrupts the interaction of multiple myeloma cells with the bone marrow microenvironment and enhances their sensitivity to therapy. Blood 2009;113:4341-4351.

10. Noh YH, Yim YS, Kim DH, Lee MW, Kim DS, Kim HR, Lee SH, Chueh HW, Choi SJ, Oh WI, Yang YS, Jung HL, Yoo KH, Sung KW, Koo HH. Correlation between chemokines released from umbilical cord blood-derived mesenchymal stem cells and engraftment of hematopoietic stem cells in nonobese diabetic/severe combined immunodeficient (NOD/SCID) mice. Pediatr Hematol Oncol 2011;28:682-690.

11. Fouillard L, Francois $\mathrm{S}$, Bouchet $\mathrm{S}$, Bensidhoum M, Elm'selmi A, Chapel A. Innovative cell therapy in the treatment of serious adverse events related to both chemoradiotherapy protocol and acute myeloid leukemia syndrome: the infusion of mesenchymal stem cells post-treatment reduces hematopoietic toxicity and promotes hematopoietic reconstitution. Curr Pharm Biotechnol 2013;14:842-848.

12. Van Overstraeten-Schloge N, Beguin $Y$, Gothot A. Role of stromal derived factor-1 in the hematopoietic-supporting activity of human mesenchymal stem cells. Eur J Haematol 2006:76:488-493.

13. Sharma MB, Limaye LS, Kale VP. Mimicking the functional hematopoietic stem cell niche in vitro: recapitulation of marrow physiology by hydrogel-based threedimensional cultures of mesenchymal stromal cells. Haematologica 2012;97:651660.

14. Burger JA, Kipps TJ. CXCR4: a key receptor in the crosstalk between tumor cells and their microenvironment. Blood 2006;107:1761-1767.

15. Van den Berk LC, van der Veer A, Willemse ME, Theeuwes MJ, Luijendijk MW, Tong WH, van der Sluis IM, Pieters R, den Boer ML. Disturbed CXCR4/CXCL12 axis in paediatric precursor B-cell acute lymphoblastic leukaemia. Br J Haematol 2014; 166:240-249.

16. Fukuhara $S$, Sako $K$, Noda $K$, Nagao $K$, Miura $K$, Mochizuki N. Tie2 is tied the cell-cell contacts and to extracellular matrix by angiopoietin-1. Exp Mol Med 2009;41:133-139.

17. Arai F, Hirao A, Ohmura M, Sato H, Matsuoka S, Takubo K, Ito K, Koh GY, Suda T. Tie2/ angiopoietin-1 signaling regulates hematopoietic stem cell quiescence in the bone marrow niche. Cell 2004;118:149-161. 
18. Blau O, Hofmann WK, Baldus CD, Thiel G, Serbent V, Schümann E, Thiel E, Blau IW. Chromosomal aberrations in bone marrow mesenchymal stroma cells from patients with myelodysplastic syndrome and acute myeloblastic leukemia. Exp Hematol 2007;35:221-229.

19. Menendez $P$, Catalina P, Rodriguez R, Melen GJ, Bueno C, Arriero M, García-Sánchez F, Lassaletta A, Garcia-Sanz R, García-Castro J. Bone marrow mesenchymal stem cells from infants with MLL-AF4+ acute leukemia harbor and express the MLL-AF4 fusion gene. J Exp Med 2009;206:3131-3141.

20. Zhao Z, Tang X, You Y, Li W, Liu F, Zou P. Assessment of bone marrow mesenchymal stem cell biological characteristics and support hematopoiesis function in patients with chronic myeloid leukemia. Leuk Res 2006;30:993-1003.

21. Karaöz $E_{1}$ Çetinalp Demircan $P$, Erman $G$, Güngörürler $E$, Eker Sarıboyacı $A$. Comparative analyses of immune-suppressive characteristics of bone-marrow, Wharton's jelly, and adipose tissue-derived human MSCs. Turk J Hematol 2017;34:213-225.

22. Choumerianou DM, Martimianaki G, Stiakaki E, Kalmanti L, Kalmanti M, Dimitriou H. Comparative study of stemness characteristics of mesenchymal cells from bone marrow of children and adults. Cytotherapy 2010;12:881-887.

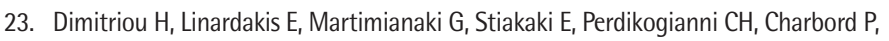
Kalmanti M. Properties and potential of bone marrow mesenchymal stromal cells from children with hematologic diseases. Cytotherapy 2008;10:125-133.

24. Nicoletti I, Migliorati G, Pagliacci MC, Grignani F, Riccardi C. A rapid and simple method for measuring thymocyte apoptosis by propidium iodide staining and flow cytometry. J Immunol Methods 1991;139:271-279.

25. Lecoeur $H_{1}$ Ledru E, Prevost MC, Gougeon ML. Strategies for phenotyping apoptotic peripheral human lymphocytes comparing ISNT, annexin V and 7-AAD cytofluorometric staining methods. J Immunol Methods 1997;209:111-123.

26. Wagner W, Horn $P$, Castoldi M, Diehlmann A, Bork S, Saffrich R, Benes V, Blake J, Pfister S, Eckstein V, Ho AD. Replicative senescence of mesenchymal stem cells: a continuous and organized process. PLoS One 2008;3:e2213.
27. Stolzing A, Jones $E$, McGonagle $D$, Scutt A. Age-related changes in human bone marrow-derived mesenchymal stem cells: consequences for cell therapies. Mech Ageing Dev 2008;129:163-173.

28. Horwitz EM, Le Blanc K, Dominici M, Mueller I, Slaper-Cortenbach I, Marini FC, Deans RJ, Krause DS, Keating A; International Society for Cellular Therapy. Clarification of the nomenclature for MSC: the International Society for Cellular Therapy position statement. Cytotherapy 2005;7:393-395.

29. Lv FJ, Tuan RS, Cheung KM, Leung VY. Concise review: the surface markers and identity of human mesenchymal stem cells. Stem Cells 2014;32:1408-1419.

30. Nagasawa T. Microenvironmental niches in the bone marrow required for B-cell development. Nat Rev Immunol 2006;6:107-116.

31. Gomes AC, Gomes MS. Hematopoietic niches, erythropoiesis and anemia of chronic infection. Exp Hematol 2016;44:85-91.

32. Nie $Y$, Han YC, Zou YR. CXCR4 is required for the quiescence of primitive hematopoietic cells. J Exp Med 2008;205:777-783.

33. Ge J, Hou R, Liu Q, Zhu R, Liu K. Stromal-derived factor-1 deficiency in the bone marrow of acute myeloid leukemia. Int J Hematol 2011;93:750-759.

34. Khandany BK, Hassanshahi G, Khorramdelazad H, Balali Z, Shamsizadeh A, Arababadi MK, Ostadebrahimi H, Fatehi A, Rezazadeh M, Ahmadi Z, Karimabad MN. Evaluation of circulating concentrations of CXCL1 (Gro- $\alpha$ ), CXCL10 (IP-10) and CXCL12 (SDF1) in ALL patients prior and post bone marrow transplantation. Pathol Res Pract 2012;208:615-619.

35. Karakurt N, Aksu T, Koksal Y, Yarali N, Tunc B, Uckan-Cetinkaya D, Ozguner M. Angiopoietins in the bone marrow microenvironment of acute lymphoblastic leukemia. Hematology 2016;21:325-331.

36. Pelagiadis I, Stiakaki E, Choulaki C, Kalmanti M, Dimitriou H. The role of children's bone marrow mesenchymal stromal cells in the ex vivo expansion of autologous and allogeneic hematopoietic stem cells. Cell Biol Int 2015;39:1099-1110.

\section{Appendix: Supplementary Materials and Methods BM MNC Isolation and MSC Culture and Expansion}

BM MNCs, following separation with Ficoll-Hypaque (1077 g/mL; Lymphoprep, Nycomed, Oslo, Norway), were cultured in a-MEM without nucleotides in the presence of 10\% lot-selected fetal calf serum (Invitrogen Ltd., Paisley, UK) as described previously [21]. They were seeded at a concentration of $5 \times 10^{4} \mathrm{cells} / \mathrm{cm}^{2}$ in the presence of $1 \mathrm{ng} /$ mL FGF-2 (FGF-2; Abcys SA, Paris, France). A complete medium change was performed twice a week. When layers became confluent at $~ 90 \%$, cells were detached using $0.25 \%$ trypsin/1 mM EDTA (Invitrogen Ltd.) and then replated at a concentration of $1 \times 10^{3}$ cells/ $\mathrm{cm}^{2}$ (passage 1, P1). MSCs were maintained in culture for up to five passages. Assays were performed at any of P1 to P4 depending on the cell availability.

\section{Immunophenotyping Evaluation}

Phenotypic characterization of MSCs was performed by flow cytometry at various passages using the following monoclonal antibodies: CD105-phycoerythrin (PE) CD146-PE, CD73-PE CD29-fluorescein isothiocyanate (FITC), CD44-FITC, CD90-FITC, CD14-FITC, CD45-FITC, CD34-PE, and CD95-FITC (BD Biosciences, San Jose, CA, USA). One hundred thousand cells were stained with the markers as described previously [21]. At least 10,000 events were acquired for each analysis.

\section{Cell-Cycle Analysis - Apoptosis}

MSCs, at either P2 or P3, after detachment by trypsinization (trypsin/EDTA 0.25\%) were centrifuged at $150 \mathrm{xg}$ for $10 \mathrm{~min}$ at $4^{\circ} \mathrm{C}$ and washed with PBS. In order to estimate the percentage of cells in each phase of the cell cycle, $1 \times 10^{6}$ MSCs were stained with $1 \mathrm{~mL}$ of propidium iodide staining solution $(50 \mu \mathrm{g} / \mathrm{mL}$ propidium iodide, $1 \mathrm{mg} / \mathrm{mL}$ RNAse in PBS without $\mathrm{Ca}^{++} / \mathrm{Mg}^{++}, \mathrm{pH}$ 7.4) for $30 \mathrm{~min}$ at room temperature. After the acquisition of at least 10,000 events for each sample, cells were gated according to forward vs. side scatter (FSC/SSC) characteristics. Cell-cycle analysis was performed using WinMDI software, version 2.8 [22].

Apoptotic MSCs at passages P2 and P4 were detected by flow cytometry and 7-aminoactinomycin D (7-AAD; Sigma, St. Louis, MO, USA) staining [23]. They were initially gated according to their morphology (FSC/SSC). Then a scattergram was generated by combining FSC with 7-AAD fluorescence to quantitate 7-AAD negative (alive), 7-AAD ${ }^{\text {low }}$ (early apoptotic), and 7-AAD high (late apoptotic/dead) cells.

\section{Cell DT}

DT was calculated according to the formula DT=t/n=txlog(2)/log (cells harvested/cells inoculated), where $t$ is the time between initial plating and harvest for the respective passage.

\section{CFU-F Formation}

At day $0.1 \times 10^{5} \mathrm{MNCs}$ were seeded in each well of a 24 -well plate (in triplicate) in the absence of FGF-2. At subsequent passages, MSCs were plated in $20-\mathrm{cm}^{2}$ petri plates at a concentration of $10 \mathrm{cells} / \mathrm{cm}^{2}$ (in duplicate). Following 14 days of culture at $37^{\circ} \mathrm{C}$ and $5 \% \mathrm{CO}_{2}$, CFU-F was quantified after staining with Giemsa stain and categorized according to size as small CFU-F (S: $<50$ cells), medium CFU-F (M: 50-500 cells), and large CFU-F (highly proliferating; L: $>500$ cells). The sum of CFU-F of all sizes is denoted as CFU-F.

\section{Detection of SDF-1 $\alpha$ and Ang-1 (ELISA)}

A quantitative sandwich ELISA was employed for the determination of both SDF-1 $\alpha$ and Ang-1 in the supernatant of MSCs at any of P1 to P3 cultures (and of MNCs at do) within the leukemia group only. All subgroups were examined for the evaluation of these factors through the whole course of the disease, diagnosis, and treatment. The ELISA kits were purchased from RED Systems, and the instructions of the manufacturer were followed. More specifically, $100 \mu \mathrm{L}$ for SDF-1 $\alpha$ (50 $\mu \mathrm{L}$ for Ang-1) of standard or sample per well was added and incubated for $2 \mathrm{~h}$ at room temperature on a shaker. After well aspiration and washing, $200 \mu \mathrm{L}$ of the corresponding conjugate was added. Incubation was continued for $2 \mathrm{~h}$ further under the same conditions. After washing $200 \mu \mathrm{L}$ of substrate solution was added to each well for $30 \mathrm{~min}$ at room temperature and then $50 \mu \mathrm{L}$ of stop solution terminated the reaction. The optical density of each well was determined at $450 \mathrm{~nm}$ with wavelength correction at $570 \mathrm{~nm}$. 